\title{
STUDI EKSPLORASI SISTEM SIARAN TELEVISI BERJARINGAN DI INDONESIA
}

\author{
K.B. Primasanti \\ Jurusan Ilmu Komunikasi, Fakultas Ilmu Komunikasi \\ Universitas Kristen Petra \\ Jalan Siwalankerto 121-131 Surabaya, 60236 \\ Email: primasanti@petra.ac.id;
}

\begin{abstract}
Television networking system is not a new theme in broadcasting. For some years, television networking system has been applied in many countries. Nowadays, Indonesia also has a willingness to apply television networking system. It is legalized trough it's broadcasting law no 32/ 2002. Unfortunately, until two periods of waiting, this regulation has not been implemented yet. Many factors are potential to be the causes of this problem; so it is a must to explore the term of television networking system and the implementation in Indonesia in order to give a mental picture about television networking system. This exploration study has explored the term of television networking system and it's application in Indonesia by refers to America's and British's as earlier country which have implemented television networking system. Trough this exploration, television networking system has been mapped into the definition: the crucial characters it has and the aspects which support it's growth. Trough the economic politic media perspective, this study has also mapped the strengths and the weaknesses of television networking system in Indonesia. This study conclude that although there must be many factors to be prepared before the implementation of television networking system, it is still possible to implement it in Indonesia trough many alternatives adjusted to our nation condition in the perspective of democtratization.
\end{abstract}

Keywords: eksploration; system; network.

\section{PENDAHULUAN}

Sistem siaran televisi berjaringan bukan merupakan tema baru dalam penyiaran. Sampai pertengahan 1980-an, sistem siaran televisi di beberapa negara di dunia didominasi oleh sistem siaran berjaringan, seperti $N B C, A B C, C B S$ (Amerika Serikat) dan Channel 4, Channel 5, BBC (Inggris). Eksistensi sistem siaran berjaringan selama bertahun-tahun seringkali diidentikkan dengan upaya menggerakkan ranah lokal dalam penyiaran untuk mewujudkan cita-cita demokratisasi. Namun, pada praktiknya, tidak jarang motif ekonomi atau politis justru lebih kuat dalam implementasinya.

Di Indonesia, sistem siaran televisi berjaringan berusaha diwujudkan dalam semangat demokratisasi melalui kebijakan desentralisasi di bidang penyiaran. Sistem siaran televisi berjaringan diidentikkan dengan pemenuhan diversity of content dan diversity of ownership sebagai prasyarat penyiaran yang demokratis. Undang-Undang No 32/ 2002 tentang Penyiaran mengamanatkan kepada semua lembaga penyiaran, 
khususnya televisi nasional untuk melakukan siaran berjaringan dengan lokal ${ }^{1}$. Kebijakan ini dikeluarkan untuk menstimulus keikutsertaan sebanyak-banyak orang untuk berusaha di dunia penyiaran serta membangkitkan potensi lokal melalui penyiaran televisi (Mufid, 2005: 147)2 .

Namun, setelah melalui periode masa tenggang (2002-2005 dan 2005-2007), kebijakan sistem siaran televisi berjaringan di Indonesia belum juga dapat berjalan. Bahkan dengan sengaja kebijakan tersebut mengalami penundaan dari pemerintahyakni Depkominfo sebagai lembaga yang berwenang. Dalam tenggang waktu ini, berbagai wacana mengenai sistem siaran berjaringan dari berbagai kelompok kepentingan berkembang sehingga memunculkan perdebatan.

Rencana penerapan sistem siaran berjaringan yang ramai diperbincangkan di Indonesia serta conflict of interest yang mengiringinya menjadi hal yang menarik untuk dikaji. Sejauh penelusuran awal yang dilakukan, kompleksitas rencana penerapan sistem siaran berjaringan di Indonesia selama ini tidak diimbangi dengan pemahaman serta rujukan yang memadai. Dengan demikian, dipandang perlu adanya penelitian eksplorasi untuk mengetahui apa itu sistem siaran berjaringan dan untuk memetakan rencana penerapan sistem siaran televisi berjaringan di Indonesia. Pembacaan atas sistem siaran televisi berjaringan ini akan dilakukan dari akar kemunculannya; penyelenggaraan dan pengelolaan sistem siaran berjaringan; serta isu yang muncul sesuai dengan konteks wilayah.

\section{PEMBAHASAN}

\section{Sistem Siaran Televisi Berjaringan}

Dengan menekankan pada "hubungan", Head dan Sterling (1987: 20) mendefinisikan siaran berjaringan atau network boradcasting system sebagai, “...two or more stations interconnected by some means of relay (wire, cable, terrestrial microwaves, satellites". Sedangkan Hiebert, Ungurait, Bohn (1974: 265) menekankan pada aspek organisasional dengan mengatakan bahwa siaran berjaringan merupakan pengorganisasian program, marketing, teknis dan administrasi dari beberapa stasiun oleh sebuah stasiun jaringan. Siregar (2001: 27) mengatakan bahwa sistem penyiaran jaringan, yaitu adanya suatu stasiun induk dengan sejumlah stasiun lokal yang menjadi periferal dalam penyiaran. Hubungan stasiun induk dengan stasiun lokal berupa pemilikan penuh atau persahaman, dan bersifat terkait dalam pasokan (feeding) program. Siaran berjaringan secara umum diartikan sebagai sistem pemasokan siaran secara sentral kepada sejumlah stasiun penyiaran (Siregar, 2001: 10).

Dalam laporan penelitiannya, Putra (1992: 20) juga merangkum bahwa, "Televisi jaringan merupakan sebuah kelompok televisi lokal, berhubung secara bersama, secara elektronis, sehingga program bisa disuplai melalui sumber tunggal yang bisa disiarkan secara serentak". Sedangkan Indonesia, dengan memberi aksentuasi pada

1 Sistem siaran televisi berjaringan yang dimaksud dalam penelitian ini adalah sistem siaran berjaringan "nasional-lokal"-mengingat sistem siaran berjaringan seringkali dimaknai secara berbeda-beda. Untuk lebih jelasnya akan dibahas dalam kerangka konsep penelitian ini.

2 Selama ini Indonesia menganut sistem siaran dengan jangkauan siar nasional. 
konsep kemitraan, UU No 32/ 2002 tentang Penyiaran menyepakati konsep siaran berjaringan sebagai kemitraan antara stasiun penyiaran lokal dengan stasiun yang bersiaran secara nasional. Dalam sistem penyiaran nasional terdapat lembaga penyiaran dan pola jaringan yang adil dan terpadu yang dikembangkan dengan membentuk stasiun jaringan dan stasiun lokal ${ }^{3}$. Sampai di sini siaran berjaringan secara umum dapat dilihat sebagai sistem penyiaran yang terdiri dari dua sub sistem, yakni stasiun induk jaringan dan anggota jaringan yang memiliki hubungan "tertentu". Selanjutnya keberadaan sistem siaran berjaringan hendaknya dikaitkan dengan faktor-faktor yang mempengaruhi serta aspek-aspek krusial yang membentuk sebuah sistem.

Pembahasan mengenai sistem ini diawali dari pandangan Browne bahwa tidak ada dua sistem penyiaran yang benar-benar sama. Ada pengaruh geografis, demografis, linguistik, ekonomi, budaya dan tekanan politis dalam suatu negara atau dari negara tetangganya. Bahkan Browne mengatakan tidak ada satu pun sistem penyiaran yang lengkap, sempurna dan cukup untuk dikatakan ideal (Brown, 1989: 3). Perbedaan cara dalam menerapkan elemen-elemen sistem penyiaran membuat sebuah sistem siaran yang satu berbeda dengan yang lain (Summers, Summers and Pennybacker, 1978: 19).

Seperti sistem siaran pada umumnya, di dalam sistem siaran televisi berjaringan juga terdapat aspek yang menentukan karakter sistem yang diterapkan. Untuk mengetahui aspek-aspek krusial tersebut, perlu kiranya membaca pandangan Summers, Summers and Pennybacker dan Browne. Summers, Summers and Pennybacker (1978: 19) mengemukakan dua aspek krusial. Pertama, berkaitan dengan mekanisme kontrol, dengan tiga kategori:

1. state ownership: fasilitas penyiaran dimiliki secara langsung oleh pemerintah dengan aktivitas penyiaran dibawah pengawasan pemerintah atau komite yang telah ditunjuk oleh pemerintah.

2. autonomous corporation: fasilitas penyiaran dimiliki dan dioperasikan oleh korporasi yang -walaupun dimiliki pemerintah-hampir seluruhnya independen dari kekuatan pemerintah.

3. private ownership: fasilitas penyiaran dimiliki dan dioperasikan oleh korporasi individu swasta, biasanya diatur dalam beberapa cara oleh badan pemerintah.

Kedua yakni aspek perencanaan keuangan (Summers, Summers and Pennybacker, 1978: 19). Pada sistem penyiaran secara umum, perencanaan keuangan ini yang juga terdiri dari tiga kategori:

1. Tax support : cara pendanaan utamanya melalui pajak.

2. Licence support : utamanya didukung oleh pembayaran ijin yang dibayar setiap tahun oleh pemilik perangkat radio atau televisi.

3. advertiser support: didukung utamanya oleh penjualan iklan untuk kepentingan bisnis dan layanan yang berharap untuk dapat mendistribusikan pesannya kepada sejumlah besar khalayak.

\footnotetext{
${ }^{3}$ Pernyataan ini terdapat dalam UU Penyiaran pasal 6 ayat 3 yang dibahas dalam artikel Hari Wiryawan (anggota Komisi Penyiaran Indonesia Daerah (KPID) Jateng), PP Penyiaran Merugikan Daerah dalam Suara Merdeka, Sabtu, 21 Januari 2006.
} 
Brown (1989: 17-59) juga memaparkan aspek krusial dalam lembaga penyiaran, yakni; financing (cara pendanaan), supervision, control and influence (pengawasan, kontrol dan pengaruh); communication policy (kebijakan komunikasi); broadcasteraudience interaction (interaksi dengan audien); dan programming (pemrograman).

Mengelaborasi pemikiran Summer, Summer and Pennybacker dan Browne tersebut, dapat ditarik beberapa aspek yang juga membentuk sistem siaran berjaringan yakni: cara pendanaan; mekanisme kontrol dan pengawasan; serta pemrograman ${ }^{4}$. Beberapa aspek ini mewujud dalam karakter yang spesifik sesuai dengan tujuan yang dicita-citakan oleh sistem siaran berjaringan yang diterapkan. Dengan demikian, aspek yang mampu membentuk sistem siaran berjaringan adalah aspek yang sesuai untuk mendukung tujuan sistem siaran berjaringan yang diterapkan.

\section{Model Siaran Televisi Berjaringan}

Beberapa definisi yang telah dipaparkan di atas menggambarkan bahwa sistem siaran berjaringan terdiri dari dua sub sistem, yakni sistem stasiun induk jaringan dan sistem stasiun anggota jaringan. Secara sederhana hubungan tersebut dapat dilihat pada bagan berikut ini.

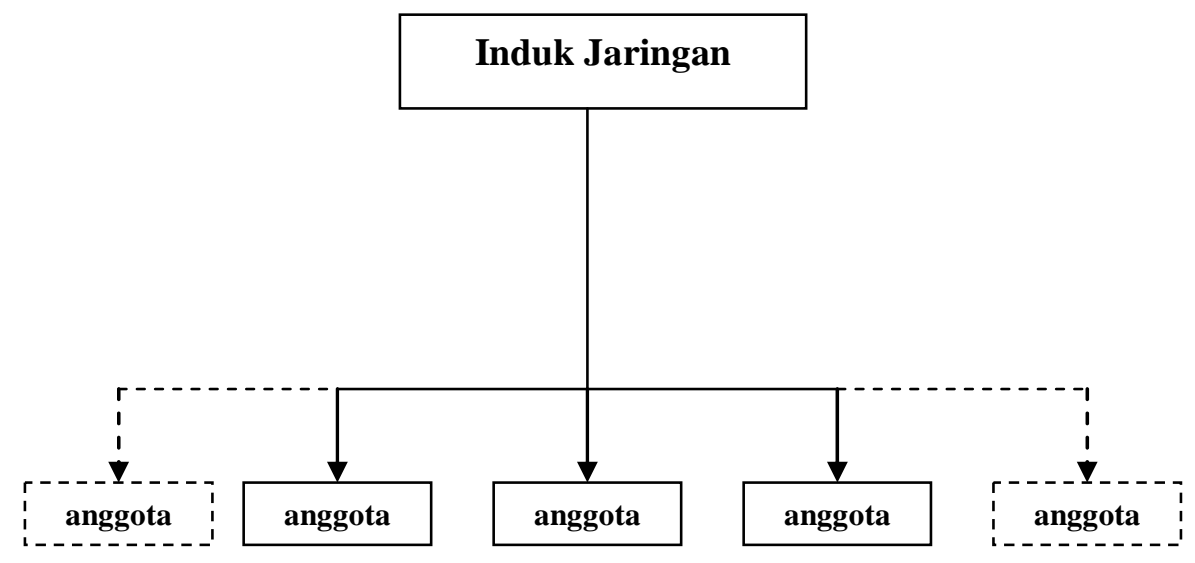

\section{Bagan 1. Model Siaran Jaringan (pemodelan dari beberapa definisi yang ada) ${ }^{5}$}

Bagan ini merupakan model sistem siaran berjaringan yang sengaja tidak dikaitkan dengan sistem yang lebih makro - seperti keterangan sebelumnya-untuk menyederhanakan pemahaman terhadap model sistem siaran berjaringannya saja. Dalam bagan tersebut, induk jaringan merupakan pusat atau sumber program atau isi siaran yang akan didistribusikan kepada stasiun-stasiun lain sebagai anggota jaringannya. Sedangkan anggota jaringan merupakan stasiun televisi penerima isi

${ }^{4}$ Mengenai mekanisme partisipasi dan evaluasi publik akan dibahas pada interaksi berbagai kepentingan dalam sistem siaran berjaringan.

5 Dalam bagan, anggota jaringan secara sederhana digambarkan dengan satu kotak, namun pada kenyataannya anggota jaringan berjumlah lebih dari satu. 
program dari stasiun jaringan. Dalam praktiknya, stasiun anggota jaringan ini merupakan stasiun yang bersiaran dalam lingkup lokal dan berjumlah lebih dari satu $^{6}$.

Induk jaringan dan anggotanya memiliki hubungan dalam hal tertentu. Dalam mengkaji hubungan stasiun induk dan anggota jaringan, terdapat dua model hubungan, yakni: Program Affiliation Network (jaringan afiliasi program) dan Owned and Operated Station (jaringan kepemilikan dan operasional).

\section{Program Affiliation Network (Jaringan Afiliasi Program)}

Dalam pola berjaringan ini, stasiun anggota jaringan tidak dimiliki oleh stasiun induknya. Kerjasama yang dibangun berdasarkan kesepakatan yang tertuang dalam kontrak, misalnya mengenai distribusi program saja. Dalam model ini, stasiun induk jaringan disebut "jaringan" (network); dan stasiun anggota jaringan dinamakan afiliasi (affiliation).

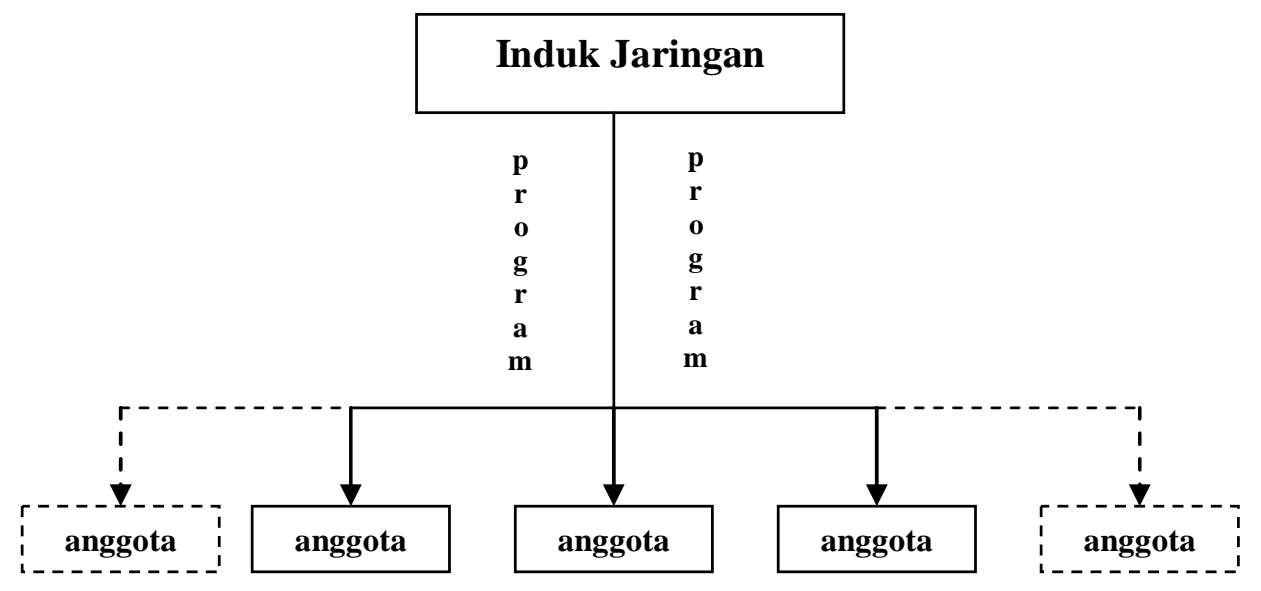

Bagan 2. Model Program Affiliation Network

Afiliasi merupakan sebuah stasiun televisi independen ${ }^{7}$-biasanya bersiaran secara lokal—dan karena kepentingan tertentu menjalin kerjasama dengan jaringan, khususnya untuk pasokan (feeding) program. Karena pada umumnya merupakan stasiun televisi lokal dan independen, maka sumber daya manusia yang ada di dalam afiliasi ini juga berasal dari ranah lokal. Dengan demikian, perbedaan wilayah dapat menyebabkan sebuah wilayah akan mendapat proporsi audien yang lebih besar dibanding wilayah lainnya.

Stasiun jaringan dan afiliasi pada umumnya diikat oleh sebuah kerjasama kontrak yang disebut affiliation contract atau affiliation agreement (Head and Sterling, 1987: 334). Dalam kontrak ini disebutkan hak dan kewajiban masing-masing

${ }^{6}$ Garis putus-putus pada bagan sistem siaran berjaringan menunjukkan bahwa jumlah anggota jaringan bisa lebih banyak lagi.

7 Stasiun independen yang dimaksud adalah stasiun yang berdiri sendiri tanpa berjaringan; memiliki manajemen sendiri. 
pihak, misalnya masing-masing berhak untuk menggunakan branding stasiunnya sendiri; anggota jaringan juga diperbolehkan menentukan jumlah stasiun induk yang akan berjaringan dengannya kecuali hal tersebut diatur dalam kesepakatan induk jaringan-afiliasi. Dalam hal manajemen pun, afiliasi diberi hak untuk mengatur mekanisme kontrol internalnya sendiri sesuai yang sudah ditetapkan oleh manajemen stasiunnya.

Tidak ada share modal maupun profit dalam model ini. Satu-satunya dana yang mengalir dari induk jaringan kepada afiliasi adalah kompensasi dari program induk yang ditayangkan oleh afiliasi. Selain itu, aliran dana berupa "sela-sela" jam tayang program induk yang dapat digunakan untuk iklan afiliasi.

\section{Owned and Operated Network (Jaringan Kepemilikan dan Operasional)}

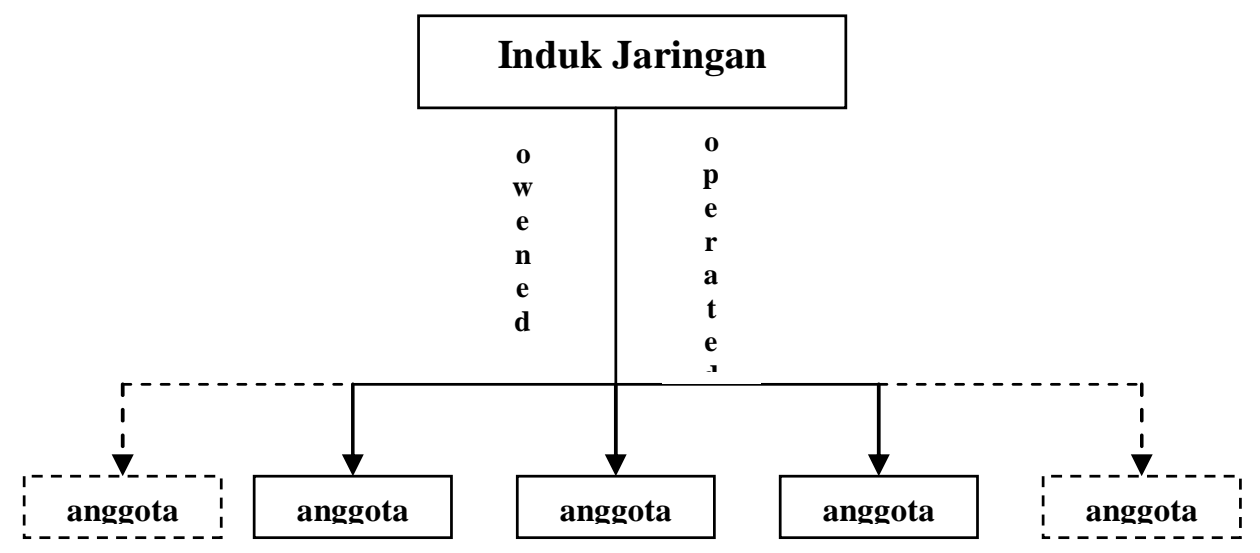

Bagan 3. Model O\&O Network

Berbeda dengan model program network affiliation, O\&O Network mensyaratkan kepemilikan jaringan atas anggotanya. Dalam pola hubungan ini, yang disebut $O \& O$ Station adalah stasiun anggota jaringan. Jadi stasiun $O \& O$ merupakan milik dari stasiun jaringan yang pada umumnya juga menggunakan nama stasiun jaringan - diikuti tanda $O \& O$, misalnya $A B C O \& O$. Kedua pihak - stasiun induk dan anggota jaringan-berada di bawah sebuah perusahaan yang sama. Dengan demikian, sistem ini bukan hanya mendistribusikan program dari jaringan kepada anggotanya melainkan berkaitan dengan kepemilikan, manajemen, dan operasionalisasi pada stasiun anggotanya.

Pada umumnya, stasiun induk jaringan dapat memiliki beberapa stasiun $O \& O^{8}$. Sedangkan, stasiun $O \& O$ hanya dapat berjaringan dengan satu induk jaringan. Jika terpaksa harus berjaringan dengan stasiun induk, hal ini dikhususkan hanya pada pasokan program saja. Stasiun induk jaringan juga memiliki hak untuk melepaskan stasiun $O \& O$; atau memberikannya kepada jaringan lainnya.

\footnotetext{
${ }^{8}$ Dalam jumlah terbatas, tergantung pada peraturan yang berlaku.
} 
Ada beberapa hal yang membedakan hubungan induk jaringan dengan anggotanya dalam program affiliation network dan O\&O Network. Perbedaan dua model kepemilikan sistem siaran berjaringan ini dapat dilihat dalam tabel berikut.

Tabel 1. Karakteristik Perbedaan Program Affiliation dan O\&O Network

\begin{tabular}{|c|c|c|}
\hline Karakteristik & Afiliasi & Stasiun $O \& O$ \\
\hline Kepemilikan & Stasiun independen & Dimiliki oleh jaringan induk \\
\hline Kesepakatan & Affiliation agreement & Tidak mutlak ada \\
\hline Isi Kerjasama & Distribusi program & $\begin{array}{l}\text { Distribusi program; } \\
\text { manajemen }\end{array}$ \\
\hline Branding & Independen & Sesuai stasiun induk \\
\hline Jumlah jaringan & Bebas terbatas & $\begin{array}{l}\text { Hanya satu jaringan induk; } \\
\text { dan jaringan lain untuk } \\
\text { distribusi program saja }\end{array}$ \\
\hline Manajemen & Independen & Stasiun induk jaringan \\
\hline Human resource & Independen & Berasal dari induk jaringan \\
\hline Share modal dan profit & $\begin{array}{l}\text { Berdasarkan kesepakatan/ } \\
\text { kontrak }\end{array}$ & $\begin{array}{l}\text { Sesuai manajemen induk } \\
\text { jaringan }\end{array}$ \\
\hline
\end{tabular}

Hubungan antara induk jaringan dengan anggota jaringan pada umumnya dijalin melalui franchise. Mengacu pada konsep yang dikemukakan International Franchise Association (IFA) franchise dalam hal ini merupakan suatu strategi pengembangan program secara komersial, berdasarkan kerjasama yang erat dan berkesinambungan antar perusahaan baik secara hukum maupun finansial, yang independen, yaitu antara induk jaringan dan anggotanya ${ }^{9}$.

Hubungan yang dijalin sistem siaran berjaringan dengan beberapa anggota jaringan-yakni dengan televisi-televisi yang berada di wilayah lokal—dan keluasan cakupan wilayah siar seringkali dianggap potensial bagi demokratisasi. Namun pada praktiknya sistem siaran berjaringan justru lebih kental dengan tujuan ekonomi atau politis tertentu. Dengan demikian ekonomi politik menjadi kerangka yang penting untuk membahas sistem siaran berjaringan. Sub bab berikut ini akan menyajikan konteks ekonomi politik dalam penerapan sistem siaran berjaringan.

\section{Konteks Ekonomi Politik}

Ada dua aliran besar yang menaungi ekonomi-politik penyiaran dalam diskursus komunikasi. Yang pertama, liberal political economy. Mufid (2005: 83) menerjemahkannya sebagai instrumen untuk melihat perubahan sosial dan transformasi sejarah sebagai suatu doktrin dan seperangkat prinsip untuk mengorganisasi dan menangani ekonomi pasar, guna tercapainya suatu efisiensi yang maksimum, pertumbuhan ekonomi dan kesejahteraan individu; sedangkan yang kedua, critical political economy yang melihat relasi antara agensi (individu dalam tema liberal) dan strtuktur (pasar dan negara) dengan lebih dinamis (Hidayat, 2001:3 dalam ibid).

${ }^{9}$ Definisi dan elemen-elemen dalam franchise terdapat dalam www.franchise.org 
Critical political economy atau kajian ekonomi politik kritis memiliki tiga varian ${ }^{10}$ : instrumentalis -yang banyak dikembangkan oleh Herman dan Chomskycenderung menempatkan agen (tindakan yang secara nyata dilakukan oleh aktor sosial atau agen) pada posisi lebih dominan dalam suatu struktur atau kultur. Media dipandang sebagai instrumen dominasi yang bisa dipergunakan sepenuhnya untuk kepentingan penguasa politik dan pemilik modal. Varian kedua adalah strukturalis yang cenderung melihat struktur sebagai totalitas yang solid dan permanen. Struktur dianggap memiliki superioritas terhadap agen. Sedangkan Golding dan Murdock (Sudibyo, 2004: 3) mengembangkan varian konstruktivis yang pada intinya melihat adanya interplay atau interaksi timbal balik antara struktur dan agen. Dalam pandangan ini, para aktor sosial (agensi) dianggap mampu merubah dan mereproduksi struktur-yang merupakan konstruksi sosial—secara konstan. Varian ekonomi politik yang terakhir inilah yang akan digunakan untuk menelisik sistem siaran berjaringan di Indonesia.

Varian ekonomi politik kritis konstruktivis-yang selanjutnya disebut ekonomi politik konstruktivis-digunakan sebagai kerangka pemikiran dalam kajian ini karena beberapa alasan. Pertama, varian ini tidak menempatkan faktor ekonomi atau politik sebagai satu-satunya faktor yang dominan dalam penyiaran. Kedua, dalam perspektif ini media tidak hanya dipandang sebagai instrumen dominasi namun juga berpotensi untuk menghambat struktur. Ketiga, konstruktivis menurut Mufid (2005: 84) melihat struktur sebagai suatu formasi yang dinamis yang secara konstan terproduksi dan berubah melalui keseluruhan praktik sosial. Keempat, adanya interaksi kekuasaan yang intens dalam penyelenggaraan sistem penyiaran di suatu negara. Konteks ekonomi politik ini seringkali dikaitkan dengan isu demokrasi.

Mufid (2005: 85) mencatat bahwa konteks ekonomi-pollitik media memiliki tiga tolok ukur sistem sosial politik yang demokratis. Pertama, peniadaan ketimpangan sosial dalam masyarakat. Kedua, pembentukan kesadaran bersama (shared consciousness) mengenai pentingnya meletakkan kepentingan bersama (public interest) di atas kepentingan pribadi. Terakhir, demokrasi membutuhkan sistem komunikasi politik yang efektif. Warga negara harus terlibat secara aktif dalam proses-proses pembentukan kebijakan yang menyangkut kepentingan umum. Mufid (ibid) merangkum tema demokrasi dalam konteks ekonomi-politik ini sbb:

Tema demokrasi, dengan demikian bisa diartikan sebagai suatu sistem sosial politik yang memberikan jaminan penuh terhadap kebebasan individu. Hanya, kebebasan tersebut baru akan berarti bila setiap individu warga negara dapat memproleh innformasi yang cukup serta memiliki keterlibatan dan partisipasi politik yang tinggi. Sebaliknya, ketiadaan informasi serta tertutupnya ruang politik bagi masyarakat hanya akan mempersulit warga untuk mempersoalkan proses alokasi kekuasaan dan sumber daya.

Keberagaman yang muncul dari kebebasan individu tadi mensyaratkan adanya pluralisme. Dalam kehidupan media, pluralisme eksternal media akhirnya menjadi

10 Dedy N Hidayat Pengajar Program Pascasarjana Ilmu Komunikasi-FISIP-UI memaparkan ketiga varian ini dalam artikelnya Dominasi Budaya Politik Istana dalam Ruang Redaksi (http://www.kompas.com/kompas-cetak/0308/16/pustaka/495623.htm) 
pilar bagi pertumbuhan demokrasi ${ }^{11}$. Berkaitan dengan hal ini, ada dua hal mengenai media dalam konteks ekonomi-politik yang hendaknya menjadi perhatian, yakni konsentrasi dan konsolidasi media. Konsentrasi media menyangkut sebaran kepemilikan media. Pemusatan kepemilikan media yang terlalu mutlakkepemilikan monopolistik, kepemilikan menyilang, dan kepemilikan oligarkidianggap tidak menguntungkan bagi demokrasi. Untuk itu, Keberagaman sumbersumber daya media semacam media penyiaran publik, media penyiaran komunitas, media penyiaran swasta, dan media penyiaran jaringan perlu mendapat posisi yang proporsional.

Selain itu, konsolidasi media yang menyangkut proporsi mengenai jumlah dan jenis media yang harus ada. Berapa banyak media penyiaran publik, media penyiaran swasta, media penyiaran komunitas, dan media penyiaran jaringan yang harus ada, bukan saja tergantung pada ketersediaan frekuensi/saluran, tetapi juga pada kecenderungan pengeluaran publik dan kebutuhan akan pluralisme isi media.

Sudibyo (2004: 9) menguatkan konteks ekonomi politik ini sebagai pemberi perhatian yang besar terhadap faktor-faktor ideologis dan politis yang pengaruhnya bersifat laten terhadap masyarakat. Mengutip pendapat James Curran, Sudibyo memaparkan empat proses sejarah yang menajdi fokus dalam tradisi kritis studi ekonomi-politik media (Sudibyo, 2004: 9): (1) Pertumbuhan media; (2) Perluasan jangkauan perusahaan dalam industri media; (3) proses komodifikasi informasi; (4) perubahan peran negara dan intervensi pemerintah.

Konteks ekonomi politik dalam media penyiaran ini menjadi dasar untuk mengkaji rencana penerapan sistem siaran berjaringan di Indonesia yang saat ini tengah ramai diperdebatkan. Sebagai pendukung kajian, sub bab selanjutnya akan memaparkan nilai-nilai dalam penerapan sistem siaran berjaringan.

\section{Nilai dalam Sistem Siaran Televisi Berjaringan}

Nilai atau value merupakan hal faktor krusial dalam mengkaji sistem siaran berjaringan. Wahyuni (2000: 4) menyebut nilai sebagai sesuatu yang terdapat pada sebuah benda dan dapat digunakan untuk mencapai tujuan tertentu. Cuilenburg dan McQuail (2003: 183) mengkategorikan nilai atau value sebagai salah satu elemen atau faktor utama yang menentukan sebuah kebijakan komunikasi. Dalam kajian ini, nilai diposisikan sebagai sebuah faktor krusial yang mempengaruhi tujuan sistem siaran berjaringan. Sehingga kerangka mengenai nilai ini perlu dibahas.

Seperti sistem penyiaran pada umumnya, sistem siaran berjaringan juga memiliki nilai politis, ekonomis dan ideologis. Nilai politis menurut Wahyuni (2000: 4) berkaitan dengan pencapaian kekuasaan ataupun kepentingan pihak-pihak tertentu, mempertahankan kekuasaan tersebut, serta memperluas kekuasaan yang telah ada. Pada umumnya, nilai ini lebih kuat pada sistem penyiaran yang diterapkan di negara-negara yang menganut sistem penyiaran sentralistik maupun paternalistik. Nilai politis yang kuat dalam sistem penyiaran di suatu negara tentu akan mempengaruhi sistem siaran berjaringan yang akan diterapkan.

${ }^{11}$ Mengenai pluralisme eksternal media ini dijelaskan dalam artikel Agenda Kebijakan Daerah oleh Amirudin dalam Suara Merdeka, 3 Agustus 2004. (http://www.suaramerdeka.com/harian/ 0408/03/opi04.htm) 
Nilai ekonomi juga melekat dalam praktik sistem siaran televisi berjaringan. Di dalam sistem penyiaran, stasiun televisi juga berperan sebagai entitas bisnis yang merupakan sarana memproduksi produk-produk kepada masyarakat dan dengan demikian berorientasi untuk keuntungan ekonomi. These network link affiliates for the purpose of delivering and selling viewers to advertiser (Baran, 2004: 246). For the owner of the lokal station, ..., the prime source of economic affluence is affiliation with a network (Wells, 1972: 63). Dalam sistem siaran berjaringan, dengan logika yang lebih komprehensif, John Vivian memaparkan bahwa dengan kualitas programnya yang mendekati ideal-akan memberikan tayangan berkualitas sehingga dapat meraih audiens secara lebih luas; hal ini berarti peluang untuk mendapatkan keuntungan dari para pengiklan pun lebih lapang ${ }^{12}$.

A network television is an asset to lokal stations. Programs offered by the network are of a quality that an individual station cannot afford to produce. With high quality network programs, stations attract larger audiences than they could on their own. Larger audiences mean that stations can charge higher rates for lokal advertisements in the six to eight minutes per hour the networks leave open affiliates to fill (Vivian, 2002: 211).

Walaupun, nilai politis dan ekonomi mewarnai penerapan sistem siaran berjaringan, namun sistem siaran berjaringan juga memiliki nilai ideologis. Nilai ideologis dari sistem siaran berjaringan mewujud dalam demokratisasi. Meyer (2002: 25) menyatakan bahwa untuk menemukan standar penyiaran demokratis, lembaga penyiaran seharusnya mengkomunikasikan segala peristiwa melalui cara dan perspektifnya sendiri sehingga memberikan karakteristik pada setiap program yang disiarkannya. Ada tuntutan terhadap media demokratis, yakni masing-masing harus memiliki karakter obyektif yang membawa pada diversitas.

The media have an extremely limited capacity to transmit a full and complete picture of the nearly limitless wealth of events that comprise reality, so they always have to pick and choose what they will feature and how they will present it. In the best case scenario, the media selection of stories will simultaneously pay special need to the interest that they suppose their audience to have and to the unique features of the events about which they are reporting ${ }^{13}$.

Prinsip demokrasi di ranah penyiaran dijalankan dengan sistem diversity of content (keberagaman isi) dan diversity of ownership (keberagaman pemilik). Semakin beragam isi siaran sesuai target komunitas pemirsa dan semakin meluasnya distribusi kepemilikan media penyiaran, maka semakin demokratislah ranah penyiaran itu (Sudibyo, 2004: xi).

Sistem siaran sebagai upaya memaknai demokrasi bertolak dari dua pijakan. Yang pertama adalah pijakan politis. Secara politis, demokrasi menghendaki adanya sesuatu yang menjamin keberagaman atau diversitas politik (Muffid. 2005: 68). Diversitas memungkinkan terjadinya aliran ide secara bebas melalui suatu instrumen

12 John Vivian dalam tulisannya Affiliate-Network Relation menjelaskan cukup detail mengenai perspektif ekonomi yang digunakan sebagai dasar penyiaran berjaringan ini.

${ }_{13}$ Meyer mencoba mendebat potensi positif media dalam mendiseminasikan demokratisasi ini. Ternyata media memiliki keterbatasan yang akan berpotensi negatif pada keberhasilan demokratisasi jika tidak menghiraukan karakter diversitasnya. 
yang berpotensi dapat diakses oleh semua orang secara merata. Jika satu dua orang atau kelompok mendominasi kepemilikan media, dan menggunakan posisi tersebut untuk mengontrol isi tampilan media, maka ketika itulah terjadi reduksi 'keberagaman sudut pandang' (heterodox view) (Muffid, 2005 : 69).

Pijakan kedua adalah aspek kultural. Salah satu keresahan yang muncul berkaitan dengan potensi negatif penyiaran adalah adanya komodifikasi budaya. Mosco mendefinisikan komodifikasi sebagai the process of transforming use values into exchange values of product whose value is determined by their ability to meer individual and social need into products whose value is set by what they can bring in the marketplace ${ }^{14}$. Mosco semua budaya diproduksi dalam konteks produksi industri budaya, ditampilkan dalam ciri yang sama dengan produk lain, yaitu standarisasi, masifikasi dan komodifikasi. Tema-tema siaran yang berbasis budaya, nilai-nilai dan keyakinan yang hidup dalam masyarakat sangat mungkin dikomodifikasikan apabila kekuasaan terpusat pada satu titik. Penyiaran hendaknya menjadi media bagi penampilan keragaman budaya sehingga komodifikasi tidak terjadi.

Dengan demikian, seperti yang diungkapkan Masduki (2003: 3), demokratisasi sebagai nilai ideologis dalam sistem penyiaran memiliki karakter independensi sumber daya manusia dan institusi siaran, pluralitas kepemilikan, pengelolaan dan orientasi isi siaran, desentralisasi dan otonomisasi penyiaran.

Tabel 2. Demokratisasi Penyiaran (Masduki, 2003 : 3)

\begin{tabular}{cll}
\hline NO DEMOKRATISASI & KETERANGAN \\
\hline 1 & $\begin{array}{l}\text { Independensi SDM (sumber daya manusia Dari pasar, negara dan kaum elit } \\
\text { dan institusi siaran) }\end{array}$ & masyarakat \\
2 & $\begin{array}{l}\text { Pluralitas kepemilikan, pengelolaan dan } \\
\text { orientasi isi siaran }\end{array}$ & $\begin{array}{l}\text { Publik, komersial, jaringan lokal dan } \\
\text { sebagainya }\end{array}$ \\
3 & Desentralisasi dan otonomisasi penyiaran & Jangkauan siaran birokrasi perijinan \\
\hline
\end{tabular}

Nilai atau value dalam penyiaran seringkali dikaitkan dengan tujuan atau goals and objective dari sebuah sistem penyiaran yang diterapkan (Cuilenberg dan McQuail, 2003 : 183). Cuilenberg dan McQuail menyebut bahwa value atau nilai akan dikenali melalui tujuan penyiaran. Perbedaan penerapan nilai-nilai yang terdapat dalam sistem siaran berjaringan tentu menghadirkan benturan kepentingan dari berbagai pihak yang berkonsekuensi pada perbedaan tujuan dari sistem yang akan diterapkan. Nilai ini pun kemudian membawa implikasi yang lebih luas dalam penerapan sistem siaran berjaringan yang akan dikaji dalam penelitian ini.

\section{METODE PENELITIAN}

\section{Jenis Penelitian}

Secara ringkas, Neuman merangkum konsep studi eksplorasi ini sebagai "Research into an area that has not been studied and in which a researcher wants to

\footnotetext{
${ }^{14}$ Dalam artikel berjudul Media Massa dalam Pendekatan Ekonomi Politik oleh Liza Dwi Ratna Dewi dalam http:/jurnal.bl.ac.id/wp-content/uploads/2007/01/BLCPM-v2-n1-artikel4-januari 2007.pdf-
} 
develop initial ideas and more focused research question”. Secara ringkas, karakteristiknya dapat dilihat dalam tabel.

Tabel 3. Karakteristik Studi Eksplorasi

\begin{tabular}{l}
\hline Exploratory Research Characteristic \\
\hline 1. Become familiar with the basic facts, setting, and concerns \\
2. Create a general mental picture of conition \\
3. Formulate and fokus questions for future research \\
4. Generates new ideas, conjectures, or hypotheses \\
5. Determine the feasibility of conducting research \\
6. Develop techniques for measuring and locating future data \\
\hline
\end{tabular}

Karakteristik yang terkandung dalam studi eksplorasi ini sesuai sebagai metode untuk menjawab pertanyaan pada penelitian ini. Studi ini akan mencoba mengeksplorasi tema sistem siaran berjaringan berdasarkan penerapannya di Amerika Serikat dan Inggris; serta mengeksplorasi rencana penerapannya di Indonesia melalui literatur. Dalam praktiknya nanti, studi ini akan membaur dengan studi deskriptif untuk memenuhi pertanyaan "how" dan "who" (Neuman, 2000: 22) yang teradapat dalam penelitian ini.

\section{Teknik Pengumpulan Data}

Teknik pengumpulan data dengan studi pustaka atau (library research) dinilai sesuai untuk penelitian ini. Dalam banyak literatur, studi pustaka disejajarkanbahkan disamakan - dengan beberapa istilah, seperti "metode dokumenter" (Gulo, 2003: 123), "studi literatur", "tinjauan literatur", serta "studi dokumen" atau "studi 'record". 'Record' hampir mirip dengan dokumen, namun bersifat insidental dan hanya bisa didapatkan dari sumbernya jika peneliti menghendaki untuk melengkapi data (Moleong, 1988: 137).

\section{Teknik Analisis Data}

Data-data yang didapat dalam studi literatur sistem siaran berjaringan di Amerika Serikat dan Inggris akan disusun berdasarkan elemen analisis yang telah ditentukan. Analisis nantinya tidak bertujuan untuk membandingkan namun mendeskripsikan penerapan sistem siaran berjaringan di kedua negara tersebut. Dari deskripsi ini akan ditarik gambaran sederhana tentang sistem siaran berjaringan dan keunikan penerapan sistem siaran berjaringan dari masing-masing negara. Hasil analisis ini secara simultan akan digunakan untuk melengkapi analisis atas rencana sistem siaran berjaringan di Indonesia. Analisis dilakukan dengan pisau analisis tertentu. Pisau analisis yang digunakan mengacu pada kerangka pemikiran yang telah disusun di awal. 


\section{KESIMPULAN}

Penerapan sistem siaran berjaringan yang berbeda-beda merupakan konsekuensi dari keragaman tujuan dan pilihan cara menerapkan beberapa aspek dalam sistem siaran berjaringan, yakni: pola berjaringan (model sistem siaran berjaringan), cara pendanaan, mekanisme kontrol dan pengawasan serta pemrograman. Keragaman tujuan dan penerapan keempat aspek ini saling berkaitan dan saling mempengaruhi dalam membentuk sistem siaran berjaringan sesuai yang dicita-citakan di sebuah negara. Keragaman ini tidak terjadi begitu saja, namun juga dipengaruhi oleh beberapa faktor.

Penelitian ini telah melakukan eksplorasi terhadap sistem siaran berjaringan dalam kajian komunikasi, yakni melalui literatur sebagai sumber datanya. Dari hasil eksplorasi ini didapatkan gambaran sederhana mengenai sistem siaran telelvisi berjaringan dan keragaman penerapannya di Amerika Serikat dan Inggris. Ciri khas yang membedakan sistem siaran berjaringan ini terletak pada tujuan dan pilihan penerapan aspek-aspek sistem siaran berjaringan, yakni pola berjaringan, cara pendanaan, mekanisme kontrol dan pengawasan, serta pemrograman. Kekhususan penerapan aspek ini memberi karakter pada sistem siaran berjaringan yang diterapkan di suatu negara.

Perbedaan penerapan sistem siaran berjaringan ini ternyata dipengaruhi oleh beberapa faktor. Faktor-faktor yang dikaji dalam penelusuran ini adalah: faktor nilai, faktor kondisi ekonomi politik, faktor geografis dan budaya, serta komitmen kelompok kepentingan dalam melaksanakan sistem siaran berjaringan. Keempat faktor ini saling terkait dan bersama-sama mempengaruhi kehidupan sistem siaran berjaringan. Faktor-faktor ini setidaknya mempengaruhi dalam hal: dilaksanakannya atau tidak kebijakan sistem siaran berjaringan di suatu negara; serta berkembang atau tidaknya sistem siaran berjaringan di suatu negara.

Di Indonesia sendiri, sistem siaran berjaringan merupakan pilihan yang telah didiskusikan dan dirumuskan beberapa kalangan dalam UU No 32/ 2002 tentang Penyiaran. Sistem siaran berjaringan dinilai sebagai terobosan dalam rangka demokratisasi penyiaran. Sistem ini dianggap mampu menciptakan diversity of content dan diversity of ownership. Apalagi jika ditinjau dari faktor nilai, geografis dan budaya yang ada di Indonesia, sistem siaran berjaringan memang perlu segera diterapkan. Namun, hingga penelitian ini dilakukan, rencana penerapan sistem siaran televisi berjaringan di Indonesia masih berjarlan dalam kegamangan.

Dalam mengkaji rencana penerapan sistem ini di Indonesia, perlu kiranya menengok sistem siaran berjaringan yang telah dilaksanakan di Amerika Serikat dan Inggris. Hendaknya menjadi perhatian bahwa untuk menerapkan sistem siaran berjaringan seperti yang telah dilaksanakan di Amerika Serikat dan Inggris, perlu kondisi-kondisi khusus, seperti: kondisi ekonomi politik yang stabil. Keberhasilan Amerika Serikat dan Inggris dalam menerapkan sistem siaran berjaringan didukung oleh kondisi ekonomi dan politik yang baik. Secara ekonomi, telah ada pemerataan pendapatan di daerah-daerah; dan secara politis, pemerintah tidak campur tangan secara langsung.

Sayangnya, di Indonesia pemerataan ekonomi dan pemenuhan hak-hak dasar warga belum merata. Selain itu, beberapa kelompok kepentingan belum mencapai kata sepakat sehingga sukar memberikan komitmen untuk mendorong sistem siaran 
berjaringan. Diprediksi ada kepentignan-kepentingan terselubung yang masih menghendaki keberadaan televisi yang bersiaran secara nasional. Indonesia pun harus segera menciptakan kondisi ekonomi politik yang stabil untuk menjamin berlangsungnya penerapan sistem siaran berjaringan.

Bagaimanapun juga, sistem siaran berjaringan telah dirumuskan dalam kebijakan dan merupakan diskusi yang panjang dari berbagai pihak yang harus dilaksanakan. Namun mengingat pra kondisi yang kurang mendukung, ada baiknya Indonesia merujuk pada beberapa alternatif yang ditawarkan. Dalam kajian ini, ada beberapa alternatif yang ditawarkan. Pertama dengan menghitung kemampuan seluruh industri penyiaran televisi yang ada. Industri yang dianggap telah mampu melakukan siaran berjaringan wajib melakukan siaran berjaringan; sedangkan industri yang masih 'merangkak' dapat melakukan siaran berjaringan secara bertahap. Alternatif lainnya, misalnya melakukan sistem siaran berjaringan secara bertahap untuk semua industri televisi swasta.

\section{Refleksi Penelitian}

Riset eksplorasi ini telah berhasil memetakan gambaran sederhana mengenai sistem siaran berjaringan dalam kajian komunikasi. Selain itu, penelusuran terhadap penerapan sistem siaran berjaringan di Amerika Serikat dan Inggris juga dapat menunjukkan bahwa sistem ini diterapkan secara beragam sesuai konteks masingmasing negara. Eksplorasi terhadap rencana pelaksanaan sistem siaran berjaringan di Indonesia pun telah dilakukan dan menghasilkan kajian dengan konteks yang spesifik. Dengan demikian, penelitian ini telah memetakan karakteristik umum sistem siaran berjaringan; serta karakteristik khusus pada penerapannya di negara yang dikaji. Pembacaan mengenai pelaksanaan sistem siaran berjaringan berhasil memetakan tujuan, aspek-aspek yang membangun kehidupan sistem siaran berjaringan yang ternyata saling terkait satu dengan lainnya; serta faktor-faktor yang mempengaruhinya. Selain itu juga memetakan rencana penerapan sistem siaran berjaringan di Indonesia sekaligus tantangan dan peluang; serta alternatifnya.

Namun, penelitian ini juga memiliki keterbatasan utama, yakni: kurangnya literatur pendukung dan sumber informasi lainnya. Akhirnya sumber yang digunakan penulis pun tidak semuanya literatur ilmiah; laporan dan berbagai artikel di internet yang relatif update juga digunakan untuk melengkapi penelitian ini. Yang kedua adalah sumber informasi yang berupa record. Penelitian ini tampaknya belum seimbang jika tidak melakukan pembacaan wacana dengan framing pihak-pihak yang berkepentingan; namun kenyataan di lapangan menunjukkan keterbatasan atas akses terhadap pihak-pihak yang berkepentingan tersebut. Perdebatan wacana yang muncul di media teraktual pun juga digunakan sebagai data pendukung dalam memetakan interaksi kepentingan yang melatarbelakangi sistem siaran berjaringan —yang termasuk dalam kajian penelitian ini.

Memang metode yang digunakan dalam penelitian ini-yakni metode eksplorasi-memiliki keterbatasan yakni hanya ingin memahami gambaran umum mengenai suatu obyek yang belum atau tidak banyak diteliti. Dengan demikian diperlukan suatu kajian lebih lanjut mengenai sistem siaran berjaringan dengan metode lain untuk melengkapi gambaran sistem siaran berjaringan maupun untuk mengkaji isu-isu lain seputar sistem siaran berjaringan ini. 


\section{DAFTAR PUSTAKA}

Abramson, Bram Dov. Media Policy After Regulation.

Baran, Stanley J. 2004. Introduction to Mass Communication: Media Literacy and Culture (3rd edition). USA: McGrawHill.

Bardoel, Joe dan Leen d'Haenens. Media Meet The Citizen: Beyond Market Mechanism and Government Regulation

Becker, Samuel L dan Churchill R. Roberts. 1992. Discovering Mass Communication (3rd edition). USA: Harper Collins Publishers.

Black, Jay dan Frederick C. Whitney. 1988. Intrtoduction to Mass Communiaction Second Edition. USA: Wm. C. Brown Publishers.

Bittner, John R. 1980. Broadcasting and Telecommunication. Third Edition. New Jersey: Prentice Hall

Bittner, John R. 1985. Mass Communication: An Introduction. Third Edition. USA: Prentice-Hall

Bittner, John R. 1991. Mass Communication: An Introduction. Fourth Edition. USA: Prentice-Hall

Browne, Donald R. Comparing Broadcasting Systems: The Experiences of Six Industrialized Nations. USA: Iowa State University Press.

Croteau, David dan William Hoynes. 2001. The Bussiness of Media: Corporate Media and the Public Interest. London \& New Delhi: Pine Forge Press.

DeFleur, Melvin L dan Everette E Dennis. 1985. Understanding Mass Communication (Second Edition). Boston: Houghton Mifflin Company

Dominick, Joseph R. 1983. The Dynamic of Mass Communication. New York: Newbery Award Records, Inc.

Dyson, Kenneth, et al. 1990. Broadcasting and New Media Policies in Western Europe: A Comparative Study of Technological Change and Public Policies. London \& New York: Routledge.

Eastman, Susan Tyler, Lewis Klein, dan Sydney W. Head. 1985. Broadcasting/ Cable Prograrmming: Strategies and Practices. Second Edition. California: Wadsworth Publishing Company.

Gulo, W. 2003. Metodologi Penelitian. Jakarta: PT Gramedia.

Hallin, Daniel C. dan Paolo Mancini. 20004. Comparing Media System: Three Models of Media and Politics. Cambridge: Cambridge University Press.

Hamad, Ibnu, et all. 2005. Jurnal Penelitian Ilmu Komunikasi “Thesis". Vol. IV/ No 1, Januari-April. Jakarta: Universitas Indonesia.

Hart, Jeffrey A. 2004. Technology, Television and Competition. California: Cambridge. 
Head, Sydney W dan Christopher Sterling. 1987. Broadcasting in America: A Survey of Electronic Media (5 ${ }^{\text {th }}$ edition). Boston: Houghton Mifflin Company.

Hiebert, Ungurait, Bohn. 1974. Mass Media IV: An Introduction toModern Communication. Newyork\&London: Longman.

Ishadi. 1999. Dunia Penyiaran: Prospek dan Tantangannya. Jakarta: Gramedia Pustaka Utama.

Janowski, Gene E.F dan David C Fuchs. 1995. Television: Today and Tomorrow. New York: Oxford University Press Inc.

Jensen, Klaus Bruhn dan Nicholas W. Jankowski (Ed.). 1991. A Handbook of Qualitative Methodologies for Mass Communication Research. USA and Canada: Routledge.

Jones, Paul. The Best of Both Worlds: Freedom of Communication and 'Positive' Broadcasting Regulation.

Kellner, Douglas. 1990. Television and The Crisis of Democracy. USA: Westview Press, Inc.

Kuswandi, Wawan. 1996. Komunikasi Massa: Sebuah Analisis Media Televisi. Jakarta: PT Rineka Cipta.

Masduki. 2003. Radio Siaran dan Demokrasi. Yogyakarta: Penerbit Jendela.

Mas'oed, Mohtar. 1999. Negara, Kapital dan Demokrasi. Jogjakarta: Pustaka Pelajar

McNair, Brian. 1995. An Introduction to Political Communication. London and New York: Routledge.

McQuail, Denis dan Sven Windahl. 1993. Communication Models for The Study of Mass Communication. Singapore: Longman Sinagpore Publishers (Pte) Ltd.

Meyer, Thomas dan Lew Hinchman. 2002. Media Democaracy: How the Media Colonize Politics. USA: Blackwell Publishing Inc.

Moleong, Lexy J. 1988. Metode Penelitian Kualitatif. Depdikbud, Direktorat Jendral Dikti, Proyek Pengembangan Lembaga Pendidikan Tenaga Kependidikan, Jakarta.

Mufid, Muhamad. 2005. Komunikasi dan Regulasi Penyiaran. Jakarta: Kencana

Neuman, Lawrence W. 2000. Social research Method. (Fourth edition). USA: Allyn and Bacon.

Newcomb, Horance. 2000. Television: The Critical View. Sixth Edition. New York: Oxford University Press

Nurtjahjo, Hendra. 2006. Filsafat Demokrasi. Jakarta: PT Bumi Aksara.

Nurudin. 2004. Sistem Komunikasi Indonesia. Jakarta: PT RajaGrafindo Persada. 
O' Malley, Tom. 1994. Closedown: The BBC and Government Broadcasting Policy 1979-92. London: Pluto Press.

Orlik, Peter B. 1992. The Electronic Media. USA: Allyn and Bacon.

Panjaitan, Hinca. 1999. Memasung Televisi: KOntroversi Penyiaran di Era Orde Baru. Institut Studi Arus Informasi.

Panuju, Redi. 1997. Sistem Komunikasi Indonesia. Yogyakarta: Pustaka Pelajar.

Pember, Don R. 1992. Mass Media in America (6 ${ }^{\text {th }}$ edition). New York: macmillan Publishing Company.

Prajarto, Nunung. ed. 2006. Media Komunikasi: Siapa Mengorbankan Siapa.

Putra, I G Ngurah. 1990. laporan Penelitian: Televisi sebagai Media Komunikasi dan Karakteristik Penontonnya. Jogjakarta: Jurusan Ilmu Komunikasi, Fisipol, UGM.

Rayner, Robert M. 1947. British Democracy: An Introduction to Citizenship. London: Longmans, Green and Co.

Sayoga, Budi. 1991. Studi Literatur tentang Pengetahuan Media Massa. Jogjakarta: Jurusan Ilmu Komunikasi, Fisipol, UGM.

Siregar, Ashadi. 2001. Menyingkap Media Penyiaran: Membaca Televisi, Melihat Radio. Jogjakarta: LP3Y

Sisk, Timothy D. 2001. Democracy at The Lokal Level. Sweden: IDEA

Sudibyo, Agus. 2004. Ekonomi Politik Media Penyiaran. Jogjakarta: LKiS

Summers, Harrison B., Summers Robert E dan John H Pennybacker. 1978. Broadcasting and The Public. California: Wadsworth Publishing Company.

Vivian, John. 2002. The Media of Mass Communication. Sixth Edition. Allyn and Bacon

Wahyudi, J.B. 1994. Dasar-Dasar Manajemen Penyiaran. Jakarta: PT Gramedia Pustaka Utama.

Wahyuni, Hermin Indah. 2000. Televisi dan Intervensi Negara. Jogjakarta: Media Pressindo

Wells, Alan (Ed.). 1972. Mass Media and Society. California: National Press Books

Zaman, Budhy Komarul. 1994. Laporan Penelitian Posisi Televisi di Tengah Masyarakat. Jogjakarta: Jurusan Ilmu Komunikasi, Fisipol, UGM.

Undang-Undang No 32 Tahun 2002 tentang Penyiaran

Peraturan Pemerintah No 50 Tahun 2005 tentang Penyelenggaraan Penyiaran Lembaga Penyiaran Swasta 
Rancangan Peraturan Komisi Penyiaran Indonesia Tentang Sistem stasiun berjaringan Lembaga penyiaran Swasta Jasa Penyiaran Televisi

Proposal Sistem Siaran Berjaringan (Komisi Penyiaran Indonesia)

Hikmarani, Challida Noor Septina. 2007. Studi Eksplorasi Tentang Penyiaran Publik. Yogyakarta: Penerbit Fisipol UGM.

Hadi, Wirastomo. 2005. Dinamika Pengelolaan Stasiun Penyiaran TV Lokal oleh Pemerintah: Studi Kasus Dinamika Pengelolaan Agropolitan Televisi oleh Dinas Infokompus Kota Batu, Jawa Timur. Yogyakarta: Jurusan Ilmu Komunikasi, Fisipol, UGM.

Putra, I Gusti Ngurah. 1992. Laporan Penelitian Pustaka Sistem Siaran untuk Indonesia. Yogyakarta: Jurusan Ilmu Komunikasi, Fisipol, UGM. 